\title{
Which technique is the best for the surgical management of empyema thoracis in children?
}

\author{
Burak Tander, Unal Bicakci, Mithat Gunaydin, Dilek Demirel, Riza Rizalar, Ender Ariturk, Ferit Bernay \\ Department of Pediatric Surgery, Ondokuz Mayis University, Samsun, Turkey
}

Kardiochirurgia i Torakochirurgia Polska 2013; 10 (2): 130-132

\begin{abstract}
Introduction: The differences between single-port (SPT) and two-port techniques (TPT) for the debridement of advanced thoracic empyema in children were evaluated.

Material and methods: Age, gender, physical findings, type of thoracoscopic intervention, the length of stay (LOS) and the duration of chest tube drainage (DCTD) were reviewed in 51 patients with thoracic empyema (33 M, 18 F). The SPT was used in 14 patients, while the TPT was used in 37 patients. In the SPT, the telescope itself was used as a dissecting tool. No other instrument was inserted during the debridement. In the TPT, the first port is made for the telescope and the second port for the surgical instrument. A chest tube is inserted through the port site.

Results: The empyema was located in the right hemithorax in 24 patients and in the left hemithorax in 25 patients. Two patients suffered from bilateral involvement. The chest tube was removed after a median of 13 days in the SPT and 11 days in the TPT patients. The LOS was a median of 20 days and 13 days in patients from the SPT and TPT groups, respectively. A spontaneously resolved bronchopleural fistula was observed in 4 patients from the SPT group and 2 patients from the TPT group. No significant difference was found between the techniques in terms of age, gender, site of empyema, fever, or the development of bronchopleural fistula. Although the LOS and DCTD were shorter in patients treated with the TPT, the difference was not significant.

Conclusions: Although not significant, the TPT for the debridement of advanced empyema in children seems to be more effective in terms of the LOS, DCTD and the risk of bronchopleural fistula.
\end{abstract}

Key words: empyema, single-port technique, two-port technique.

\section{Streszczenie}

Wstęp: Ocenione zostały różnice między jednoportowymi (single-port techniques - SPT) oraz dwuportowymi (two-port techniques - TPT) metodami usuwania ropniaka opłucnej u dzieci. Materiał i metody: Od 51 pacjentów z ropniakiem opłucnej (33 mężczyzn, 18 kobiet) pobrano następujące dane: wiek, płeć, wyniki badań przedmiotowych, typ torakoskopii, długość pobytu w szpitalu (lenght of stay - LOS) oraz czas trwania drenażu klatki piersiowej (duration of chest tube drainage DCTD). Metodę SPT zastosowano u 14 pacjentów, a TPT u 37. W przypadku SPT jako narzędzie tnące używany jest sam teleskop. Podczas procesu oczyszczania do organizmu nie wprowadza się innych narzędzi. W przypadku TPT pierwszy otwór używany jest do wprowadzenia teleskopu, a drugi przeznaczony jest dla narzędzia chirurgicznego. Przez jeden z otworów wprowadzany jest następnie dren.

Wyniki: U 24 pacjentów ropniak znajdował się w prawej części klatki piersiowej, natomiast u 25 pacjentów umiejscowiony był po lewej stronie. $U$ dwóch pacjentów klatka piersiowa była obustronnie zajęta. W grupie SPT dren był usuwany z klatki piersiowej po średnio 13 dniach, natomiast $w$ grupie TPT po średnio 11 dniach. Średni LOS wynosił odpowiednio 20 i 13 dni dla grup SPT i TPT. U 4 pacjentów z grupy SPT i 2 pacjentów z grupy TPT wystąpity samoistnie ustępujące przetoki oskrzelowo-opłucnowe. Nie stwierdzono istotnych różnic między zastosowanymi metodami w zależności od wieku, płci, miejsca wystąpienia ropniaka, gorączki i pojawienia się przetoki oskrzelowo-opłucnowej. Zarówno LOS, jak i DCTD były krótsze w przypadku pacjentów z grupy TPT, jednakże różnica ta nie była istotna statystycznie.

Wnioski: Mimo że różnice nie są wielkie, metoda TPT używana do usuwania zaawansowanego ropniaka u dzieci wydaje się bardziej efektywna pod względem LOS, DCTD oraz ryzyka wystąpienia przetoki oskrzelowo-opłucnowej.

Stowa kluczowe: ropniak, metoda jednoportowa, metoda dwuportowa.

Address for correspondence: Prof. Burak Tander, Department of Pediatric Surgery, Ondokuz Mayis University, Kurupelit, 55139 Samsun, Turkey, tel. +905322825227, e-mail: btander@omu.edu.tr 


\section{Introduction}

Empyema thoracis is defined as the accumulation of purulent material within the pleural space. The most common cause of empyema in children is bacterial pneumonia ranging from simple parapneumonic effusion to complicated loculated empyema [1]. There are several treatment options for curing empyema, such as tube thoracostomy, fibrinolytics, open decortication via thoracotomy, and thoracoscopic debridement. The debate concerning the most appropriate method for children is still ongoing [2]. Apart from the type of treatment, the timing of intervention is also a matter for discussion. Thoracoscopic drainage with the debridement of empyema is a popular method of treatment, widely used in children when conservative treatment fails. Many authors have suggested that additional thoracoscopy yields better results than tube thoracostomy alone for the primary treatment of empyema $[3,4]$. In our previous article we demonstrated the efficiency of our own technique utilizing balloon-assisted single-port thoracoscopy for debridement [5]. The prolonged hospital stay and chest tube drainage duration in some patients with advanced empyema led us to use two ports for thoracoscopic debridement. The aim of this study was to compare the single-port and two-port techniques for the thoracoscopic debridement of empyema.

\section{Material and methods}

Fifty-one patients (33 male, 18 female) with advanced empyema thoracis were evaluated between May 2002 and December 2012. The outcome parameters were age, gender, physical findings, the type of thoracoscopic surgery, microorganism cultures, the length of stay (LOS) and the duration of chest tube drainage (DCTD). The singleport technique (SPT) was performed on 14 patients and the two-port technique (TPT) on 37 patients. Antibiotic regimens were provided to all patients in our department (sultamicillin, gentamycin, clindamycin). After December 2006, all thoracoscopies were made via two ports. Thoracic $C T$ scans were performed in all cases with pulmonary compression caused by adhesion or empyema. In the SPT group, the telescope itself was used as a dissection tool for separating adhesions. The entire debridement and dissection were performed with the telescope. No other instrument was inserted during the dissection and debridement. Postoperatively, a chest tube was inserted through the trocar entry site [5]. In the TPT group, one port was made for the telescope and another one was made for debridement. After the dissection of the septa and the debridement, a chest tube was inserted through one of the trocar holes. In all cases, material for microbiologic analysis was obtained during thoracoscopy. All patients received broadspectrum antibiotics.

\section{Statistical analysis}

Statistical analysis was performed using SPSS 16.0 software. Descriptive statistics were prepared and the groups were compared using the chi-square test or Fisher's exact test; normality tests were performed, followed by one-way ANOVA or Kruskal-Wallis analysis of variance.

\section{Results}

Fever was the primary symptom in all patients. Cough, respiratory distress, and general poor health were found in many patients as well. The total number of patients in the SPT group was 14 (7 male, 7 female) and the total number of patients in the TPT group was 37 (26 male, 11 female) (Table I).

Intraoperatively, all patients had serious adhesions with fibrin septa, which were separated and aspirated. These were all stage 3 , advanced cases.

Twenty-two patients had right-sided empyema (10 in the SPT group, 12 in the TPT group), and twenty patients had left-sided empyema ( 6 in the SPT group, 14 in the TPT group). Two patients had bilateral empyema, both of whom were in the TPT group. The median duration of chest tube drainage (DCTD) was 11 days in the SPT group and 9 days in the TPT group. The median length of stay (LOS) was 20 days in the SPT group and 13 days in the TPT group. Limited and spontaneously resolving bronchopulmonary fistulas were found in 4 and 2 patients in the SPT and TPT groups, respectively (Table I). Secondary surgery was not necessary in the SPT group, but in the TPT group, two patients (5.4\%) underwent secondary interventions due to debridement failure. Microbiological analysis revealed positive cultures for microorganisms in seven patients (three instances of Streptococcus pneumoniae and one of each of the following: Staphylococcus aureus, Acinetobacter spp., non-specific fungi, and Mycobacterium tuberculosis).

There was no difference between the groups with regard to age $(p=0.9)$, sex $(p=0.15)$, the side of empyema $(p=0.51)$, fever $(p=0.26)$, the need for further surgery $(p=0.48)$, or the development of bronchopulmonary fistula $(p=0.06)$. The LOS was significantly shorter in the TPT group than in the SPT group $(p=0.05)$. The DCTD was not statistically significant $(p=0.46)$.

\section{Discussion}

It is possible for parapneumonic effusion to progress to empyema. The thick septa formed by fibrin and cellular

Tab. I. Features of single port thoracoscopy (SPT) and two-port thoracoscopy (TPT)

\begin{tabular}{lcc} 
& SPT & TPT \\
Right hemithorax, $n$ & 8 & 16 \\
\hline Left hemithorax, $n$ & 6 & 19 \\
\hline Bilateral, $n$ & 0 & 2 \\
\hline Median DCTD, days (range) & $11(3-28)$ & $9(4-22)$ \\
\hline Median LOS, days (range) & $20(9-32)$ & $13(5-54)$ \\
\hline Bronchopulmonary fistula, $n$ & 4 & 2 \\
\hline Fever, $n$ & 10 & 27 \\
\hline Cough/respiratory distress, $n$ & 13 & 26 \\
\hline
\end{tabular}

DCTD - duration of chest tube drainage; LOS - length of stay 
debris block lung expansion during inspiration, resulting in the deposition of purulent fluid between multiloculated septa rather than in free fluid accumulation [6]. Conservative treatment modalities, such as antibiotics, tube drainage, and fibrinolytics, may fail under such circumstances $[7,8]$.

The change from simple effusions to the more serious stages, such as multiloculated effusions or empyema, is progressive. The stages of empyema are classified into three groups - exudative, fibrinopurulent and organizing $[9,10]$. The determination of the stage of empyema is not always simple. The progress to the third stage is often rapid and the disease is often not diagnosed until it enters the organizing phase.

Up to $40 \%$ of pneumonia patients develop parapneumonic effusions despite appropriate initial antibiotic therapy [11-13]. Surgical intervention is inevitable in the case of progression to complex complicated parapneumonic effusion or complex empyema. If the less invasive methods (thoracentesis, chest tube drainage alone or with fibrinolytics, open thoracotomy or thoracoscopy) turn out to be ineffective the dissection of the septa and further debridement may be necessary [14-16].

In recent years, thoracoscopy has become popular in the treatment of empyema. Many authors have suggested that thoracoscopy is more advantageous as the initial treatment than tube thoracostomy alone [17-19]. Shah's multicenter study supports the early use of thoracoscopy, pointing to shorter hospital stays and fewer instances of further surgery [20]. Indeed, the separation and washing out of the septa allows for better visibility inside the thoracic cavity and more efficient expansion of the affected lung [21]. Additionally, the placement of a chest tube at the desired angle through thoracoscopy may provide more effective postoperative drainage [22]. In the current study, these findings were observed in both groups.

Martinez-Ferro et al. indicated in their prospective study that the SPT is a safe method and has better cosmetic results than the TPT [23]. In our series, all patients suffered from advanced empyema and, in our opinion, the clinical outcomes provided by the SPT were, in many cases, far from satisfactory. We suggest that the SPT may be sufficient only for patients in the less severe phases of empyema. In contrast, the TPT is more effective in patients with multiloculated, thick fibrin septa. Although it was not statistically significant, we found that the LOS and DCTD were shorter in the TPT group.

We found that two-port thoracoscopy provides better visibility and ensures easier dissection and debridement of the thorax than single-port thoracoscopy.

To conclude, we consider the TPT to be more useful for successful dissection and debridement in patients with extremely thick septa of late-stage empyema. In simple, single-septum empyema, the SPT is as effective as the TPT and the type of thoracoscopy should be determined according to the structure and stage of the empyema.

\section{References}

1. Shen YH, Hwang KP, Niu CK. Complicated parapneumonic effusion and empyema in children. J Microbiol Immunol Infect 2006; 39: 483-488.

2. Aziz A, Healey JM, Qureshi F, Kane TD, Kurland G, Green M, Hackam DJ. Comparative analysis of chest tube thoracostomy and video-assisted thoracoscopic surgery in empyema and parapneumonic effusion associated with pneumonia in children. Surg Infect 2007; 9: 317-323.

3. Doski JJ, Lou D, Hicks BA, Megison SM, Sanchez P, Contidor M, Guzzetta PC. Management of parapneumonic collections in infants and children. J Pediatr Surg 2000; 35: 265-270.

4. Merry CM, Bufo AJ, Shah RS, Schropp KP, Lobe TE. Early definitive intervention by thoracoscopy in pediatric empyema. J Pediatr Surg 1999; 34: 178-181.

5. Tander B, Ustun L, Ariturk E, Rizalar R, Ayyildiz SH, Bernay F. Balloon- assisted single port thoracoscopic debridement in children with thoracic empymema. J Laparoendosc Adv Surg Tech A 2007; 17: 504-508.

6. Light RW, Rodriguez RM. Management of parapneumonic effusions. Clin Chest Med 1998; 19: 373-382.

7. Molnar TF. Current surgical treatment of thoracic empyema in adults. Eur Cardiothorac Surg 2007; 32: 422-430.

8. Colice GL, Curtis A, Deslauriers J, Heffner J, Light R, Littenberg B, Sahn S, Weinstein RA, Yusen RD. Medical and surgical treatment of parapeumonic effusions: An evidence-based guideline. Chest 2000; 118: 1158-1171.

9. Aydogan M, Aydogan A, Ozcan A, Tugay M, Gokalp AS, Arisoy ES. Intrapelural streptokinase treatment in children with empymema. Eur J Pediatr 2008; 167: 739-744.

10. Ekingen G, Guvenc BH, Sozubir S, Tuzlaci A, Senel U. Fibrinolytic treatment of complicated pediatric thoracic empyemas with intrapleural streptokinase. Eur Cardiothoracic Surg 2004; 26: 503-507.

11. Koegelenberg CF, Diacon AH, Bolliger CT. Parapneumonic pleural effusion and empyema. Respiration 2008; 75: 241-250.

12. Light RW. Parapneumonic effusions and empyema. Proc Am Thoracic Soc 2006; 3: 75-80.

13. Chapman SJ, Davies RJ. Recent advances in parapneumonic effusions and empyema. Curr Opin Pulm Med 2004; 10: 299-304.

14. Gates RL, Hogan M, Weinstein S, Arca MJ. Drainage, fibrinolytics, or surgery: A comparison of treatment options in pediatric empyema. J Pediatr Surg 2004; 39: 1638-1642.

15. Chen LE, Langer JC, Dillon PA. Management of late-stage parapneumonic empyema. J Pediatr Surg 2002; 37: 371-374.

16. Kern JA, Rodgers BM. Thoracoscopy in the management of empyema in children. J Pediatr Surg 1993; 28: 1128-1132.

17. Hornick P, Townsend ER, Clark D, Fountain SW. Videothoracoscopy in the treatment of early empyema: An initial experience. Ann R Coll Surg Engl 1996; 78: 44-48.

18. Angelillo Mackinlay TA, Lyons GA, Chimondeguy DJ, Piedras MA, Angaramo G, Emery J. VATS debridement versus thoracotomy in the treatment of loculated postpnuemonia empyema. Ann Thorac Surg 1996; 61: 1626-1630.

19. Sendt W, Forster E, Hau T. Early thoracoscopic debridement and drainage as definite treatment for plueral empyema. Eur J Surg 1995; 161: 73-76.

20. Shah SS, DiCristina CM, Bell LM, Ten HT, Metlay JP. Primary early thoracoscopy and reduction in length stay and additional procedures among children with complicated pnuemonia. Arch Pediatr Adolesc Med 2008; 162: 675-681.

21. Gossot D, Stern JB, Galetta D, Debrosse D, Girard P, Caliandro R, Harper L, Grunenwald D. Thoracoscopic management of postpneumonectomy empyema. Ann Thorac Surg 2004; 78: 273-276.

22. Kercher KW, Attorri RJ, Hoover JD, Morton D. Thoracoscopic decortication as first-line therapy for pediatric parapneumonic empyema. Chest 2000; 118: 24-27.

23. Martínez-Ferro M, Duarte S, Laje P. Single port thoracoscopy for the treatment of pleural empyema in children. J Pediatr Surg 2004; 39: 1194-1196. 